\title{
Enel experience in the environmental management of maintenance of hydroelectric reservoirs
}

\section{Expérience de l'ENEL dans la gestion environnementale des opérations de maintenance des réservoirs hydroélectriques}

Vitali R., Bartoletti G., loannilli E.(1)

(1) ENEL S.p.A. DCO/LP, Via Bixio 39, 29100 Piacenza, Italy.

\begin{abstract}
Environmental concerns linked with extraordinary maintenance of hydroelectric reservoirs have been emphasized in Italy in recent years. ENEL manages more than 240 hydroelectric plants fed by reservoirs mostly located in the Aips and in the Apennines (and so relatively unpolluted), for a power production of about 30 billions $\mathrm{kWh} / \mathrm{y}$.

At present in Italy there is not yet a specific national legislation that regulates these maintenance operations from the environmental standpoint, so the conditions for the grant of the permit for their execution are object of case by case negotiations with local competent Authorities.

In the last years ENEL has been gathering experiences in monitoring the impact of emptying and cleaning reservoirs on the physico-chemical and biological characteristics of water downstream of the dams and in environmentally sound allocation of fine sediments, considering all available options (agricultural recycling, land filling, river bank and coastal reprofiling, downstream dritting, dumping). On the basis of the results of these surveys, combined with a review of other European and North-American works, guidelines for performing these operations in condition of environmental safeguard and for related monitoring have been defined with the aim to propose an uniform procedural scheme to all competent Authorities.

In this paper the basic experiences and judgements for determining the relevant criteria of the guidelines are presented.
\end{abstract}

Résumé. - Les problèmes d'environnement liés à la maintenance des réservoirs hydroélectriques se sont accrus en Italie au cours des dernières années. ENEL exploite plus de 240 centrales hydroélectriques alimentées par des réservoirs localisés principalement 
dans les Alpes et les Apennins, de ce fait relativement peu pollués, ce qui représente une production annuelle d'environ 30 milliards de $\mathrm{kWh}$. L'Italie n'a pas encore de législation nationale pour réglementer spécifiquement les opérations de maintenance sous l'aspect environnemental, c'est pourquoi l'obtention des autorisations relatives à ces opérations fait l'objet de négociation au cas par cas avec les autorités locales compétentes. Dans les dernières années, l'ENEL a acquis une expérience dans le domaine de la surveillance de l'impact des vidanges et chasses de réservoirs. Cela concerne d'une part les caractéristiques physico-chimiques et biologiques en aval des barrages et d'autre part le devenir des sédiments fins en considérant les différentes options possibles : recyclage agricole, épandage, reprofilage des berges ou des côtes, élimination vers l'aval, mise en décharge.

A partir de celte expérience et des travaux européens et nord-américains, des recommandations en vue de minimiser l'impact environnemental de ces opérations et d'établir une surveillance appropriée ont été définies avec la volonté de proposer un schéma unique à toutes les autorités compétentes. Les données de base et les interprétations sur lesquelles sont fondées ces recommandations sont présentées dans cet article.

\section{INTRODUCTION}

Environmental concerns linked with extraordinary maintenance of hydroelectric reservoirs have been emphasized in ltaly in recent years.

ENEL manages more than 240 hydroelectric plants fed by reservoirs mostly located in the Alps and in the Apennines (and so relatively unpolluted), for a power production of about 30 billions $\mathrm{kWh} / \mathrm{y}$.

At present in Italy there is not yet a specific national legislation that regulates these maintenance operations from the environmental standpoint, so the conditions for the grant of the permit for their execution are object of case by case negotiations with local competent Authorities.

In the last years ENEL has been gathering experiences in monitoring the impact of emptying and cleaning reservoirs on the physico-chemical and biological characteristics of water downstream of the dams and in en- vironmentally sound allocation of fine sediments, considering all available options (agricultural recycling, land filling, river bank and coastal reshaping, downstream drifting, dumping). On the basis of the results of these surveys, combined with a review of other European and North-American works, guidelines for performing these operations in condition of environmental safeguard and for related monitoring have been defined with the aim to propose an uniform procedural scheme to all competent Authorities.

in this paper the basic experiences and judgements for determining the relevant criteria of the guidelines are presented.

\section{ENEL EXPERIENCES}

We report here some remarkable ENEL experiences in monitoring the downstream impact of extraordinary maintenance operations of reservoirs accomplished from 1989 to 1992. 
Figure 1 and table I report the location and the main characteristics of the reservoirs surveyed. Most of them are located in the Northern Apennines, at altitudes of 318 to $1225 \mathrm{~m}$., in areas with low population density;

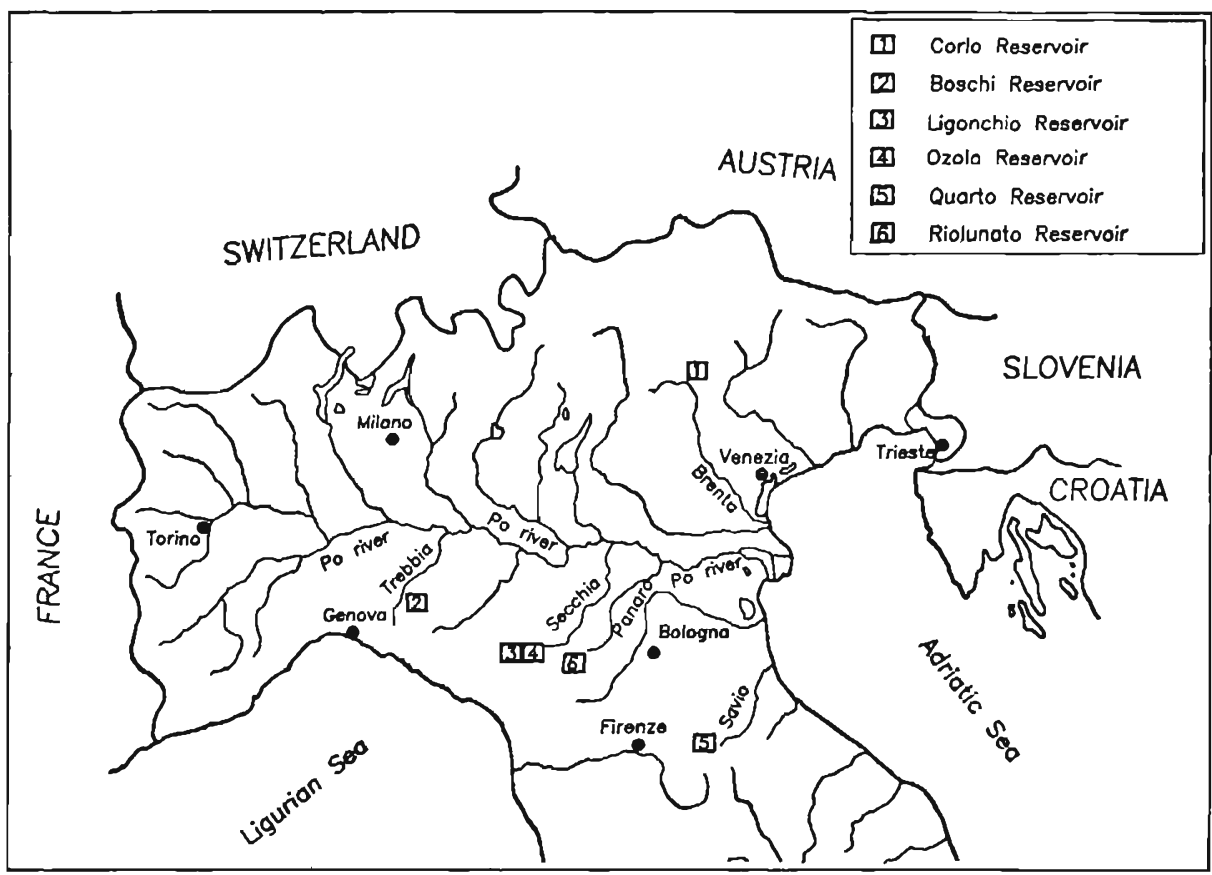

Fig. 1. - Geographical location of the reservoirs.

Table I. - Main characteristics of the reservoirs monitored.

\begin{tabular}{|c|c|c|c|c|c|c|c|}
\hline Reservoir & $\begin{array}{c}\text { Idrograph1c } \\
\text { basin }\end{array}$ & stream & $\begin{array}{l}\text { Altitude } \\
\text { (m.a.a.l.) }\end{array}$ & $\begin{array}{c}\text { Catchement } \\
\text { area } \\
\left(\mathrm{km}^{2}\right)\end{array}$ & $\begin{array}{l}\text { Total } \\
\text { Capacity } \\
\mathrm{m}^{3} \cdot 10^{6}\end{array}$ & $\begin{array}{c}\text { Operation } \\
\text { accomplished }\end{array}$ & Date \\
\hline BOSCHI & $\begin{array}{l}\text { Trebbla } \\
\text { River }\end{array}$ & Aveto & 615 & 170 & 1,18 & Emptying & May 1991 \\
\hline OZOLA & $\begin{array}{l}\text { Secchla } \\
\text { River }\end{array}$ & ozola & 1225 & 13 & 0,10 & 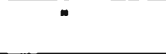 & July \\
\hline $\begin{array}{l}\text { QUARTO DI } \\
\text { ROMAGNA }\end{array}$ & $\begin{array}{l}\text { Savio } \\
\text { River }\end{array}$ & Savio & 318 & 215 & 4,54 & - & July \\
\hline
\end{tabular}


one of them is situated in the Eastern Alps at $268 \mathrm{~m}$.

Their catchment area ranges from 4 to $628 \mathrm{~km}^{2}$ and their capacity from 0,10 to $4,54 \mathrm{~m}^{3} \cdot 10^{6}$. Table II reports the capacity loss caused by sedimentation during the life of the reservoirs.

The plan carried out to survey the impact of the maintenance operations is based on monitoring the main physico-chemical characteristics of water downstream of the dam, with special regard to Total Suspended Solids (TSS) and Dissolved Oxygen (DO), during the drawdown and after it, until the water quality perturbation subsides; because of the low level of population density in the catchment basins (and of the low organic matter concentration expected in the sediment of the reservoirs), $\mathrm{NH}_{3}$ has not been considered.

To evaluate the impact on stream biological components, bottom macroinvertebrates have been monitored to estimate a hydrobiological quality index based on the dominance relationship between sensitive and tolerant species; this index (Extended Biological Index, EBI) has been fitted to the italian context (Ghetti, 1986) from British and French experiences (Woodiwiss, 1964; Verneaux, 1973) and, at present, it is currently used by local Authorities to evaluate stream pollution. The score of EBI (from 14 $=$ excellent to $0=$ poor) is ranked in 5 quality classes (from 1 = excellent to $\mathrm{V}=$ poor). $\mathrm{EBI}$ monitoring was accomplished 1 to 2 months before and 1 to 2 months after each drawdown operation; in some cases, the postoperational survey was repeated more than once.

Generally, both physico-chemical and hydrobiological parameters were checked at three locations downstream of the reservoir, whose distances from the dam are reported in table III.

Table II. - Capacity loss for sedimentation of the reservoirs monitored.

\begin{tabular}{|c|c|c|c|}
\hline Reservolr & Year & $\begin{array}{c}\text { Total Capacity } \\
\left(\mathrm{m}^{3} * 10^{6}\right)\end{array}$ & $\begin{array}{l}\text { Filling } \\
\left(m^{3} \star 10^{6}\right)\end{array}$ \\
\hline CORLO & $\begin{array}{l}1953 \\
1989\end{array}$ & $\begin{array}{l}48,60 \\
44,11\end{array}$ & 4.49 \\
\hline BOSCHI & $\begin{array}{l}1930 \\
1984\end{array}$ & $\begin{array}{l}1,18 \\
0,78\end{array}$ & 0,40 \\
\hline $\begin{array}{l}\text { LIGONCHIO } \\
(*)\end{array}$ & $\begin{array}{l}1921 \\
1990\end{array}$ & $\begin{array}{l}0,18 \\
0,18\end{array}$ & - \\
\hline QUARTO & $\begin{array}{l}1925 \\
1990\end{array}$ & $\begin{array}{l}4,54 \\
0,60\end{array}$ & 3,94 \\
\hline RIOLUNATO & $\begin{array}{l}1920 \\
1990\end{array}$ & $\begin{array}{l}0,60 \\
0,06\end{array}$ & 0,54 \\
\hline
\end{tabular}

(*) Reservolr with asphalted bottom 
In two sites of particular naturalistic interest (Corlo and Riolunato), also an ichthyological survey was accomplished, sampling by quantitative electrofishing the stretches downstream of the dam, before and after the maintenance operations.
The optimal options for the allocation of the fine sediments, consistent with the Italian legislation on solid wastes, were selected following the procedure outlined in figure 2.

According to this scheme, sediments are firstly subjected to toxicity

Table III. - Distance from the dam of the monitoring reaches $(\mathrm{km})$.

\begin{tabular}{|l|c|c|c|}
\hline Reservoir & Reach 1 & Reach 2 & Reach 3 \\
\hline CORLO & 3 & $13,5(0)$ & $20(0)$ \\
BOSCHI & 2 & 9 & 10,5 \\
LIGONCHIO & 1 & 2 & $7(0)$ \\
OZOLA & 1 & 2 & - \\
QUARTO & 1 & 5,5 & 12 \\
RIOLUNATO & 2 & 6,5 & 12 \\
\hline
\end{tabular}

$(0)=$ Reach downstream of the confluence into the main river

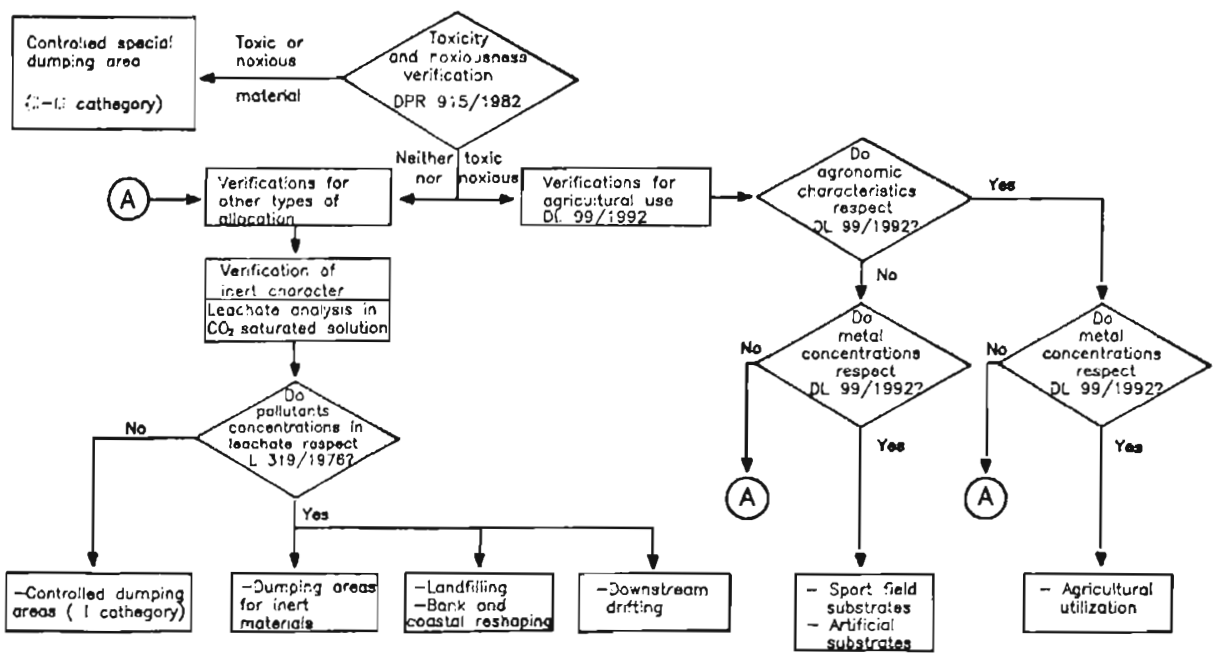

Fig. 2. - Criteria for classification and allocation of the sediments from reservoirs. 
and noxiousness verification, according to the decree DPR 915/1982; if they result toxic or noxious, their allocation must be accomplished into special controlled dumping sites (II-III category).

If they result neither toxic nor noxious, two options can be selected in consideration of local opportunities: verification of their character of inert materials or their agricultural recycling.

The possibility to consider sediments as inert is verified by leachate analysis in $\mathrm{CO}_{2}$ saturated water solution; if their concentration of pollutants is over the reference values prescribed by the law on liquid wastes ( $L$ 319/1976), they must be allocated in I category controlled dumping sites; if their concentration of pollutants respects the limits of $L 319 / 1976$, they can be addressed to inert dumping sites, drifted in the stream bed downstream of the dam or used for land filling or river bank reshaping.

The procedure for agricultural recycling is regulated by the decree DL 99/1992; if agronomic characteristics of sediments do not observe the reference values of this legislative act, metal concentrations must be considered: in case that neither the latter do, the options depending on the verification of their character of inert materials must be selected. On the contrary, if metal concentrations comply with the law, the fine sediments can be used for sport fields, parks, artificial substrates.

Also if agronomic characteristics of sediments respect DL 99/1992, while metal concentrations do not, the options depending on the verification of their character of inert materials must be taken into consideration. The agricultural utilization of fine sediments is permitted only in the case that both agronomic characteristics and metal concentrations comply with the law.

\subsection{Impact on water quality and hydrobiology}

\section{Corlo reservoir}

Its cleaning intervention was controlled by monitoring the DO in the reach 1, on the Torrent Cismon, at $3 \mathrm{~km}$ from the dam; the water release from the reservoir was stopped whenever its concentration at reach 1 fell under $4 \mathrm{mg} / \mathrm{l}$. So it was possible to maintain the daily average of TSS under $10 \mathrm{~g} / \mathrm{l}$ (with the only exception of the fourth day) and that one of DO between 9 and $11,5 \mathrm{mg} / \mathrm{l}$ (fig. 3).

The delay of the increase of TSS (the maximum concentration was measured on the fourth day) was due to the release of surface water (relatively clean) during the first days. The time extent of the perturbation was of about 2 weeks; the TSS increase was pointed out as far as $20 \mathrm{~km}$ downstream of the dam, where another reservoir (Mignano res., on the Brenta river) abated it.

The EBI decrease was showed only in the reach 1 , because the other monitoring locations were situated downstream of the confluence of the T. Cismon into the Brenta river, that 

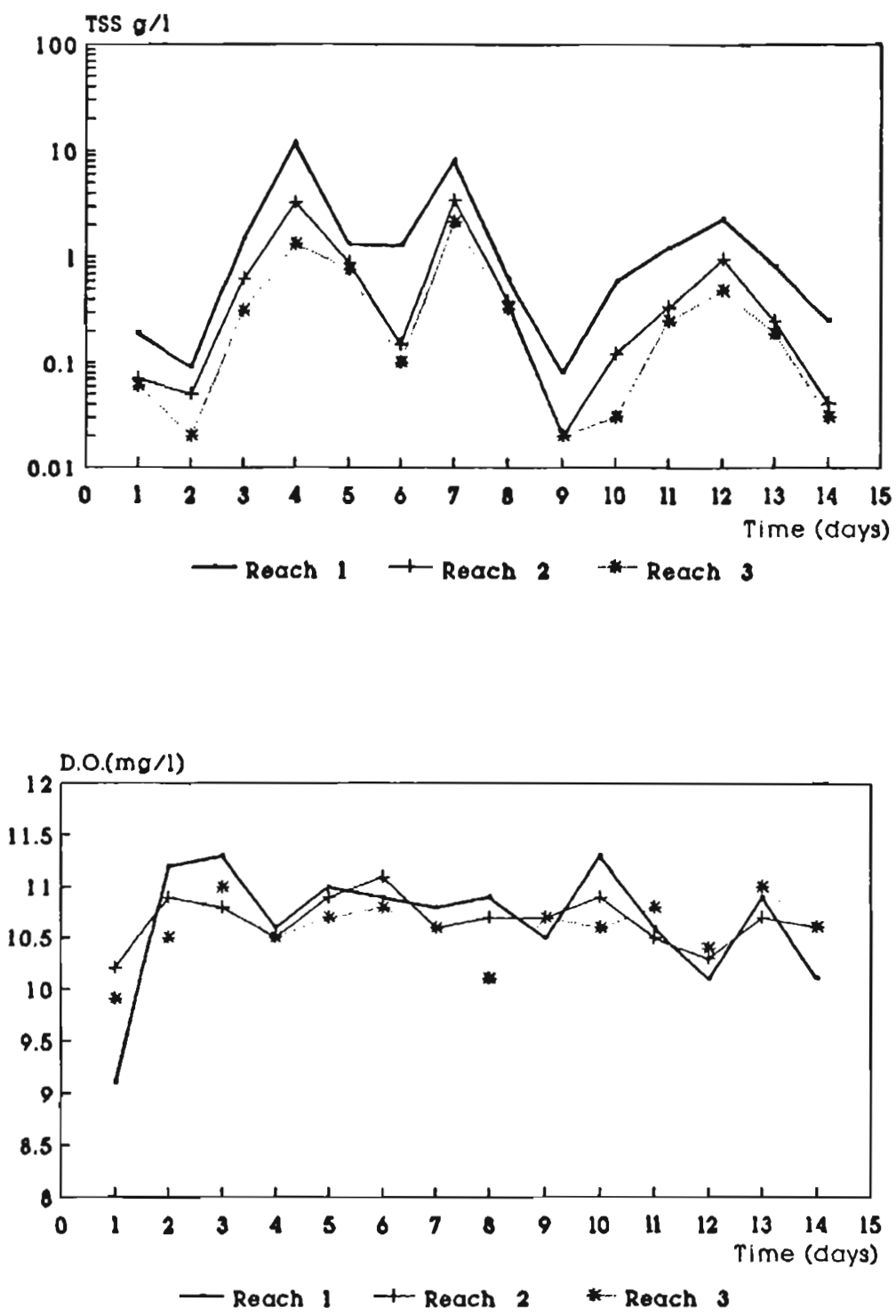

Flg. 3. - Corlo reservoir TSS and DO (daily averages) downstream of the dam after emptying.

mitigated the impact of the main- of water course (T. Cismon and tenance operation with its flow.

In this site, also an ichthyological survey was accomplished, monitoring quantitatively by electrofishing $40 \mathrm{~km}$ Brenta river), before and after the release from the dam; the data collected shows that the impact of the maintenance intervention did not in- 
fluenced the structure and abundance of fish population, mostly constituted by Salmonids; the main effect pointed out was the shift downstream of the dam of a fraction of the lacustrine fish population that lived in the Corlo reservoir.

\section{Boschi reservoir}

This reservoir was emptied taking as a reference two threshold-values for TSS: $6 \mathrm{~g} / \mathrm{l}$ at the reach 1 (T. Aveto, $2 \mathrm{~km}$ from the dam) and $1 \mathrm{~g} / \mathrm{l}$ at the reach 2 (T. Aveto, $9 \mathrm{~km}$ from the dam). The intervention was accomplished operating the intake of the hydroelectric plant fed by the reservoir, the mid-water and the bottom discharge in such a way as to drift downstream as little as possible quantity of sediment and stopping the water release when the limits were overcome.

The thresholds were exceeded in some occasions for three days and the consequent correcting intervention succeeded in lowering TSS (fig. 4).

Spot measurements were accomplished also downstream of the confluence of $\mathrm{T}$. Aveto with the Trebbia river, to point out the spatial extent of the perturbation: it reached $30 \mathrm{~km}$ from the dam at the fifth day and decreased to $<10 \mathrm{~km}$ at the eighth day (fig. 5). At the reach 1 the water quality variation lasted about 12 days.

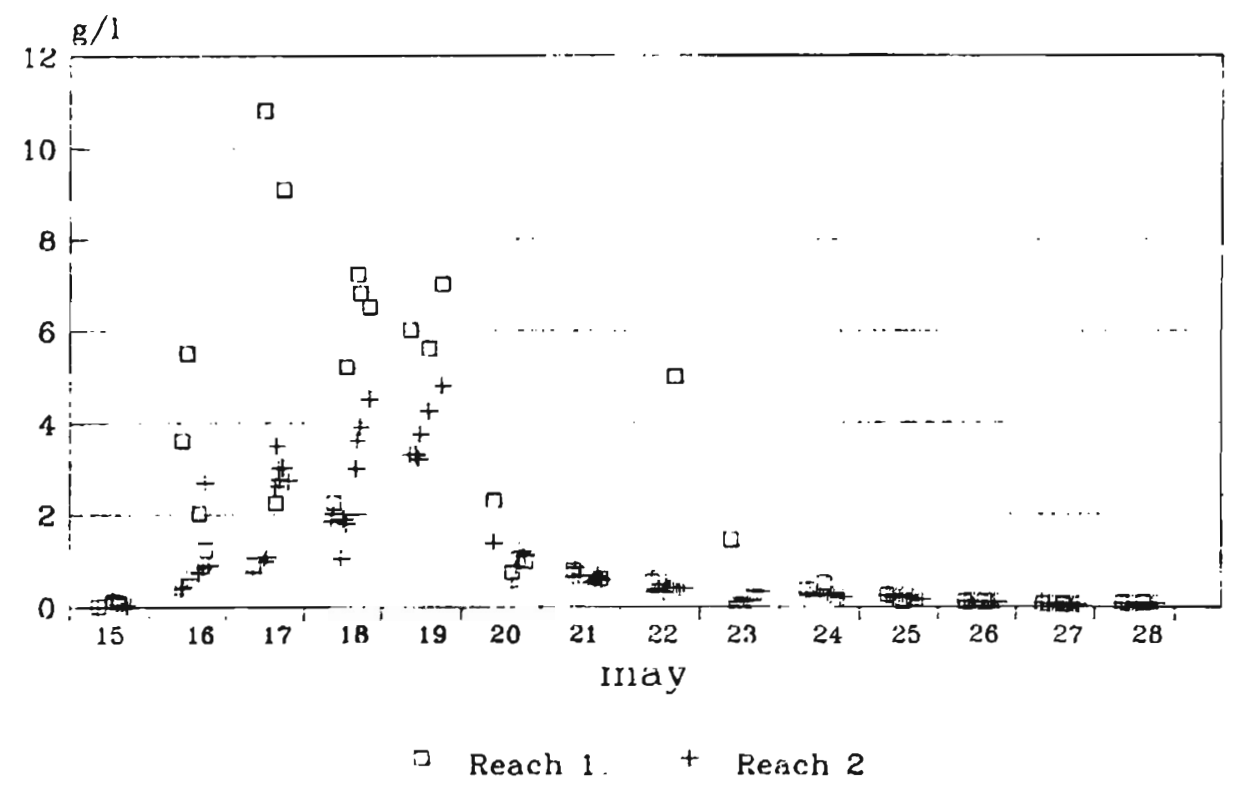

Fig. 4. - Boschi reservoir. TSS downtream of the dam after emptying. 


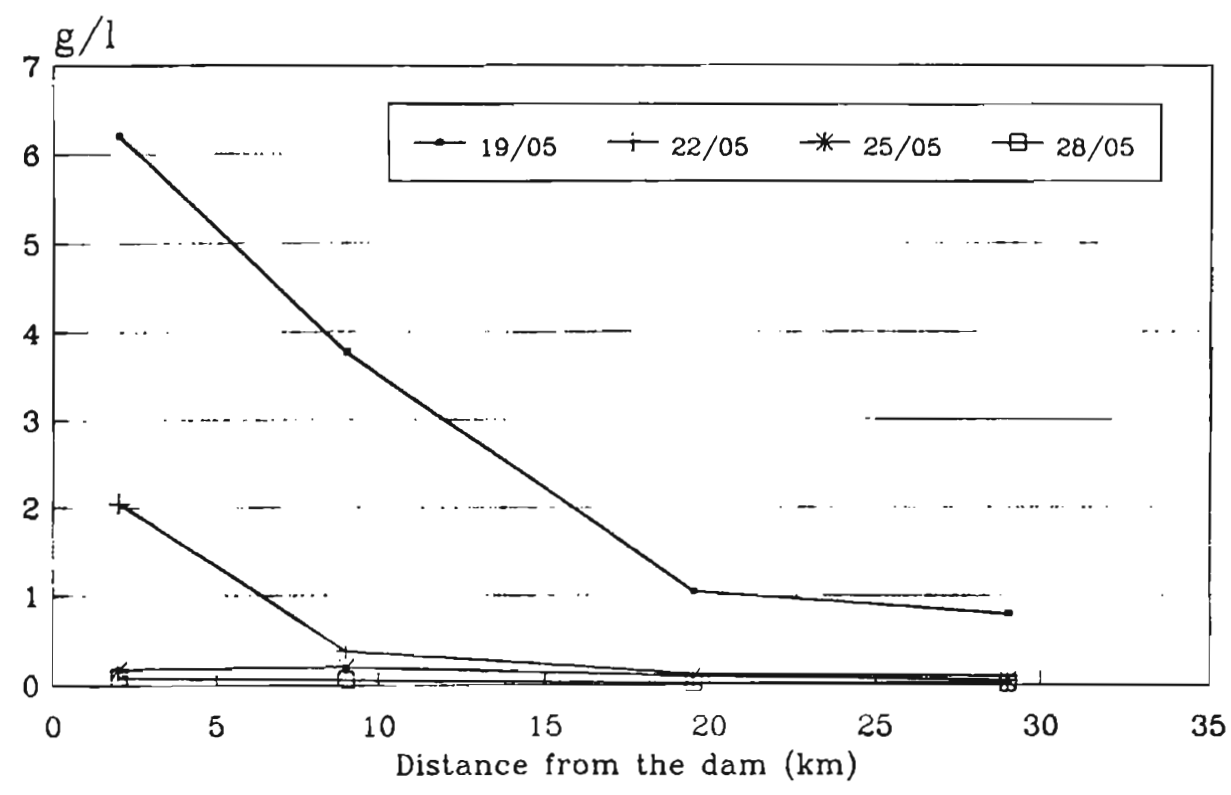

Fig. 5. - Boschi reservoir TSS downstream of the dam at different dates after emptying.

After the end of the drawdown, because the discharge gear remained open for the maintenance works, TSS increased occasionally for the erosion of fractions of the dry sediment on the bottom of the reservoir and for flood events.

The EBI survey was protracted for the following seasonal cycle (tab. IVa to c). The light decrease of quality (from the I to the II class) affected the three monitoring reaches for the subsequent year; at present, the monitoring activity is going on, to verify the time of recovery.

The reach 3 showed the biological effects of the perturbation before the reach 2 , probably because it is 10 cated downstream of the water resti- tution of the hydroelectric plant fed by the Boschi reservoir and, so, directly exposed to a part of the water release during the drawdown.

\section{Ligonchio and Ozola reservoirs}

The emptying operations for these reservoirs did not present particular problems from the environmental standpoint. Their catchment basin, in fact, is very little and the amount of sediment drifted downstream was low, so the perturbation of TSS did not last long (figs. 6 to 7). No monitoring reach showed EBI score decrease.

\section{Quarto reservoir}

The perturbation of TSS consequent to the water release from this reservoir was relatively short and it 
Table IVa. - Boschi reservoir - EB.I. downstream of the dam - Reach 1.

TAXON

$\begin{array}{ll}\text { PLECOPTERA: } & \text { Isoperla } \\ & \text { Perla } \\ & \text { Amphinemura } \\ & \text { Protonemura } \\ & \text { Leuctra } \\ & \text { Nemoura } \\ & \text { Brachyptera }\end{array}$

EPHEMEROPTERA: Habroleptoides Rhithrogena

Ecdyonunis

Ephemerella

Baetis

Epeorus

Habrophlebia

TRICHOPTERA:

COLEOPTERA:

DIPTERA:

HIRUDINEA:

OLIGOCHAETA:

Hydropsychidae Polycentropodidae

Psychomyidae

Rhyacophilidae

Philopotamidae

Beraeidae

Sericostomatidae

Gyrinidae

Elminthidae

Helodidae

Dytiscidae

Hydrophilidae

Limoniidae

Chironomidae

Simuliidae

Tipulidae

Empididae

Tabanidae

Dixidae

Rhagionidae

Blephariceridao

Dugesia

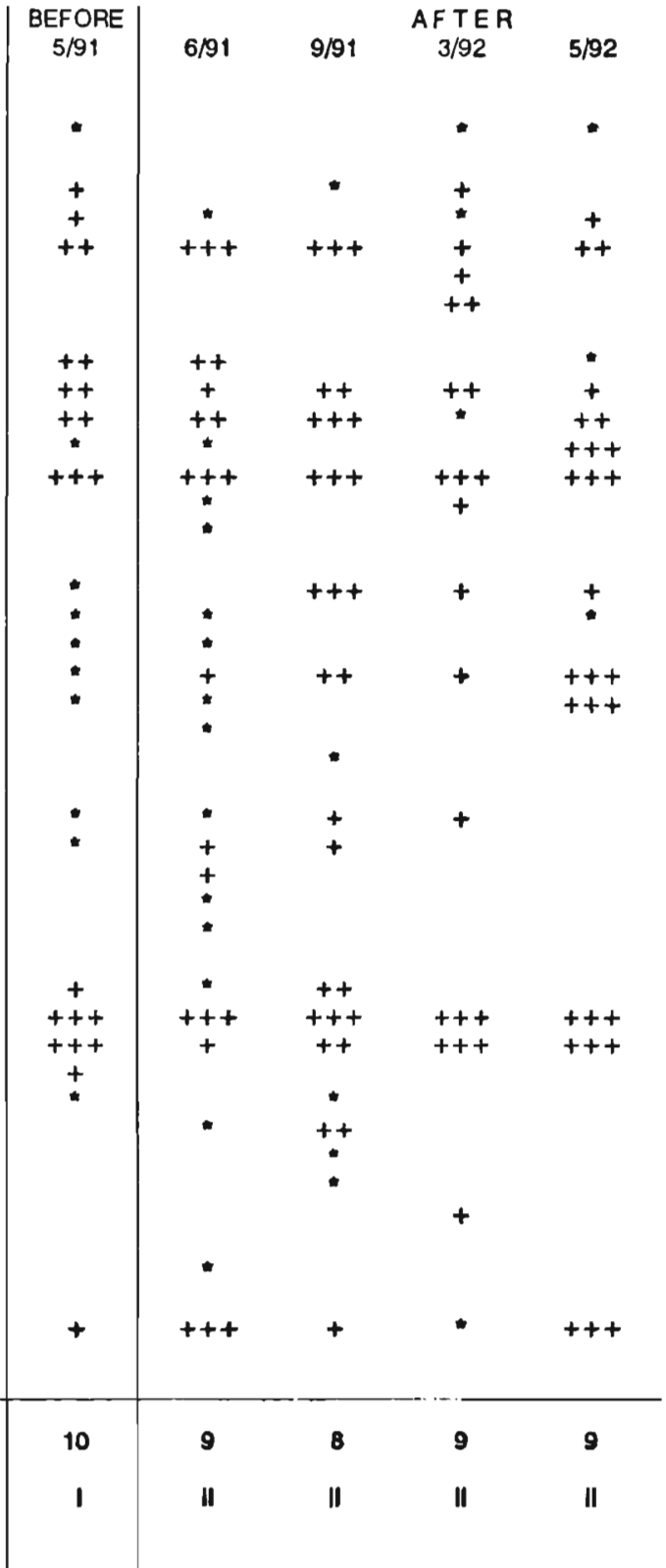

- $\quad$ occasional

$+\quad=$ rare $\div$ frequent

$++\quad=$ frequent + abundant

$+t+=\infty$ minant

E.B.I. $(14=$ excellent; $0=$ poor $)$

Qual. class $(\mid=$ exc.; $V=$ poon $)$ 
Table IVb. - Boschi reservoir - E.B.I. downstream of the dam - Reach 2.

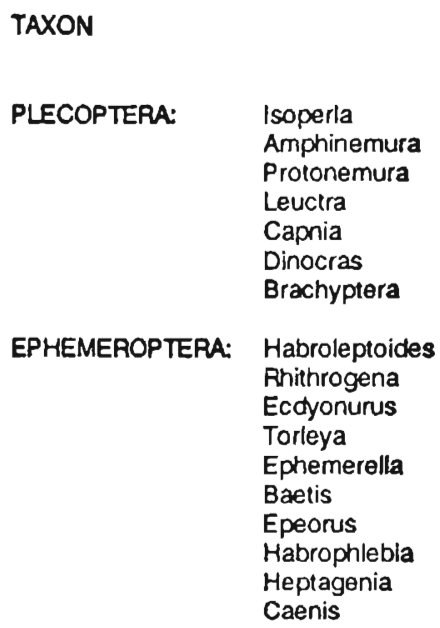

EPHEMEROPTERA: Habroleptoides Rhithrogena Ecdyonurus Torleya

Ephemerella

Baetis

Epeorus

Habrophlebla

Heptagenia

Caenis

TRICHOPTERA: Hydropsychidae Polycentropodidae Psychomyidae Rhyacophilidae Philopotamidae Beraeidae Glossosomatidae Limnephilidae Hydroptilidae

COLFOPTERA:

DIPTERA:

Gyrinidae Elminthidae

Helodidae

Dytiscidae Hydraenidae

Limoniidae

Chironomidae

Simuliidae

Anthomyidae

Stratiomyidae Blephariceridae

Athericidae

Dolichopodidae

Tabanidae

\section{GASTROPODA: Ancylus \\ HIRUDINEA: \\ Dugesia}

\section{OLIGOCHAETA:}

E.B.I. $(14=$ excellent; $0=$ poor $)$

Qual. class ( $1=$ exc.; $V=$ poor)

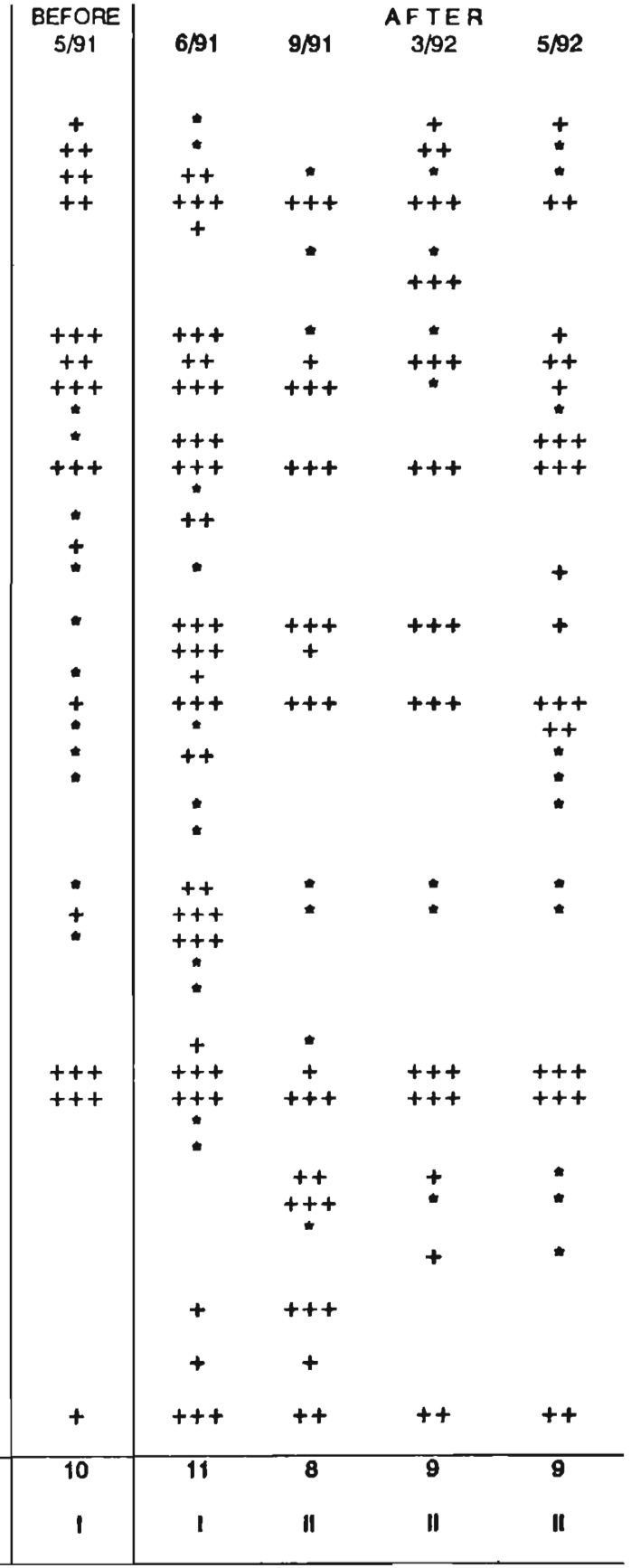

- = occasional

$+=$ rare + frequent

$$
++=\text { frequent } \div \text { abundant }
$$

$++=$ dominant 
Table IVc. - Boschi Reservoir - E.B.I. downstream of the dam - Reach 3.

TAXON

Amphinemura

Protonemura

Leuctra

Dinocras

Brachyptera

Perla

EPHEMEROPTERA: Habroleptoides

Rhithrogena

Ecclyonuns

Ephemerella

Baetis

Habrophlebia

TRICHOPTERA: Hydropsychidae

Polycentropodidae

Psychomyidae

Rhyacophilidae

Philopotamidae

Limnephilidae

COLEOPTERA:

DIPTERA:

GASTROPODA: Ancylus

OLIGOCHAETA:

Elminthidae

Helodidae

Hydrophilidae

Gyrinidae

Hydraenidae

Dytiscidae

Limoniidae

Chironomidae

Simuliidae

Tabanidae

Tipulidae

Empididae

Dolichopodidae

Alhericidae

Blephariceridae

Strationyidae
PLECOPTERA: Isoperla

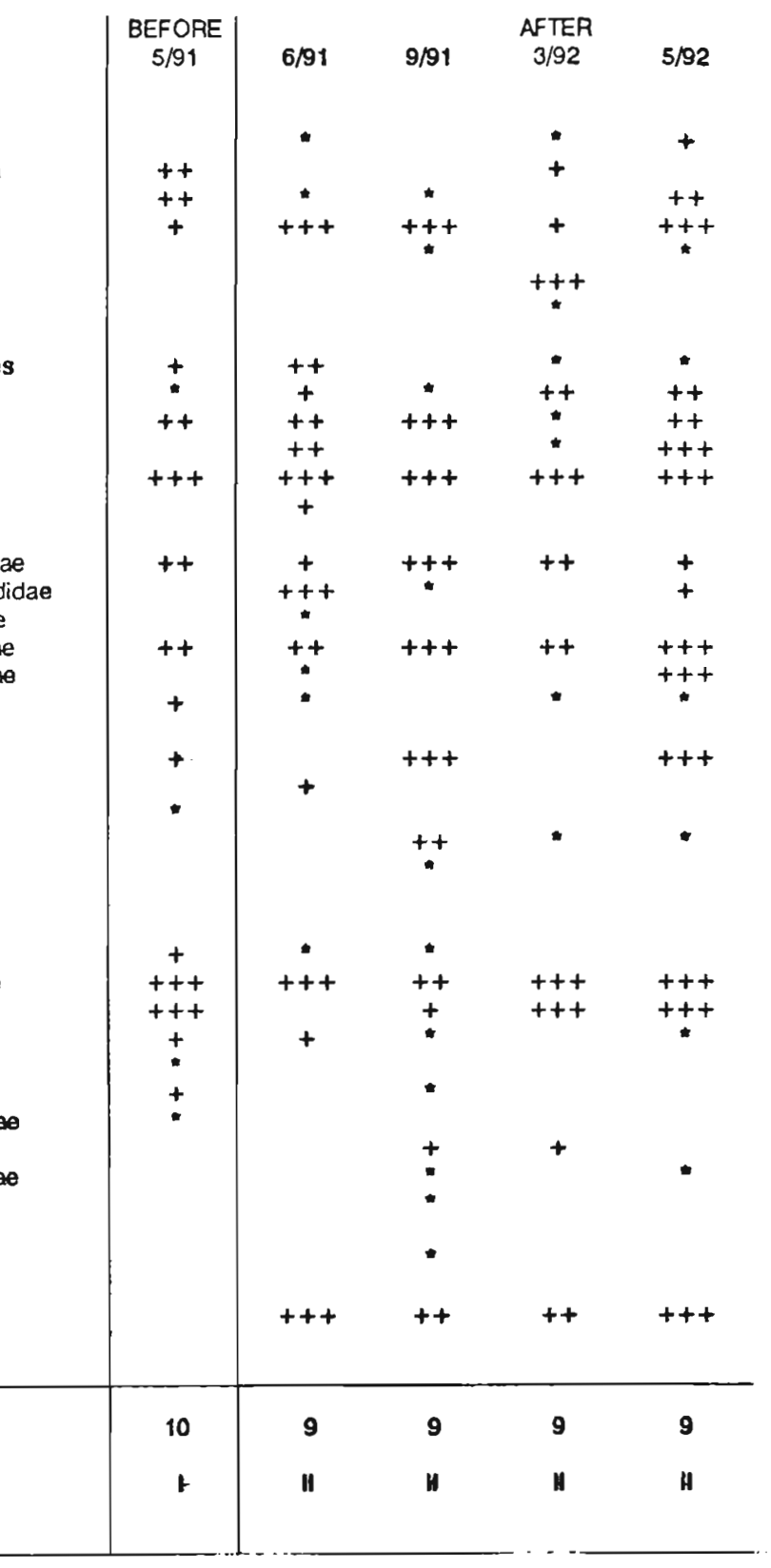

E.B.I. $(14=$ excellent; $0=$ poor $)$

Qual. class $(1=$ exc.; $V=$ poor $)$
- = occasional

$+\quad=$ rare $\div$ frequent

$++=$ frequent $\div$ abundant

$+++=$ dominant 

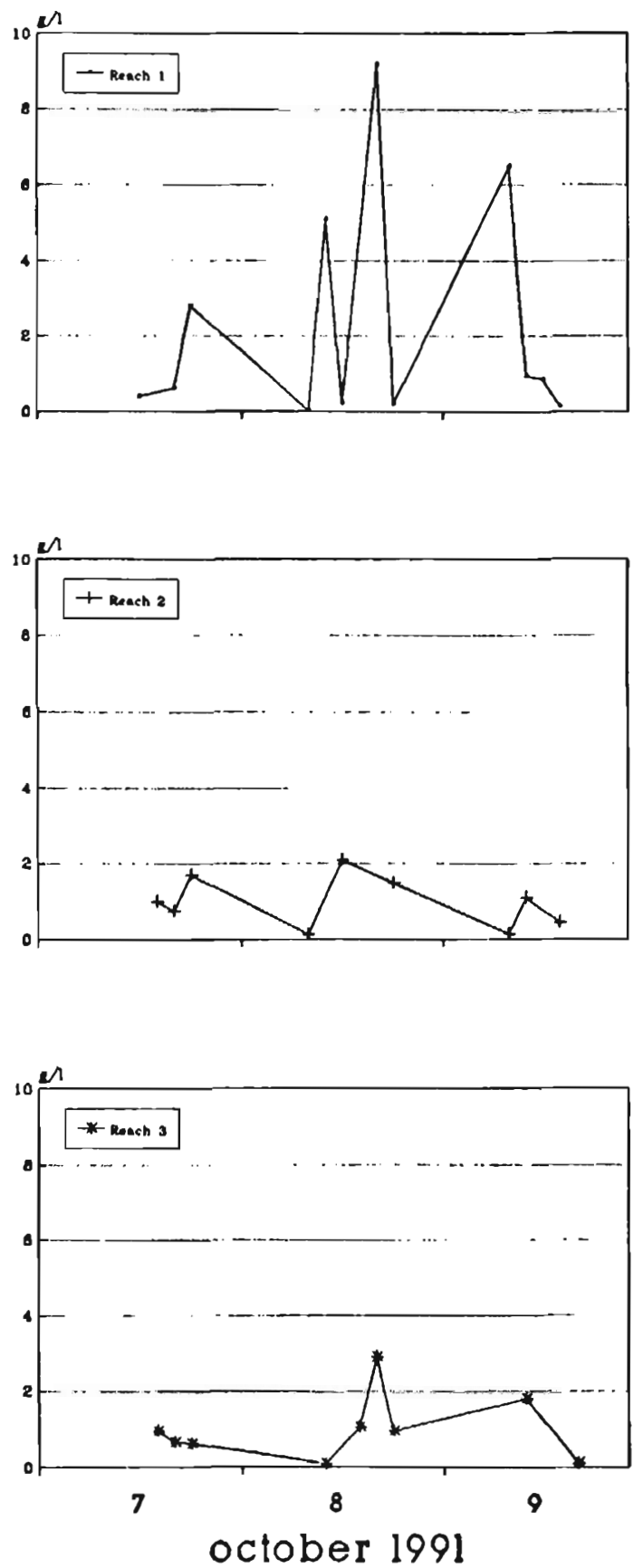

Fig. 6. - Ligonchio reservoir TSS downstrem of the dam after emptying. 

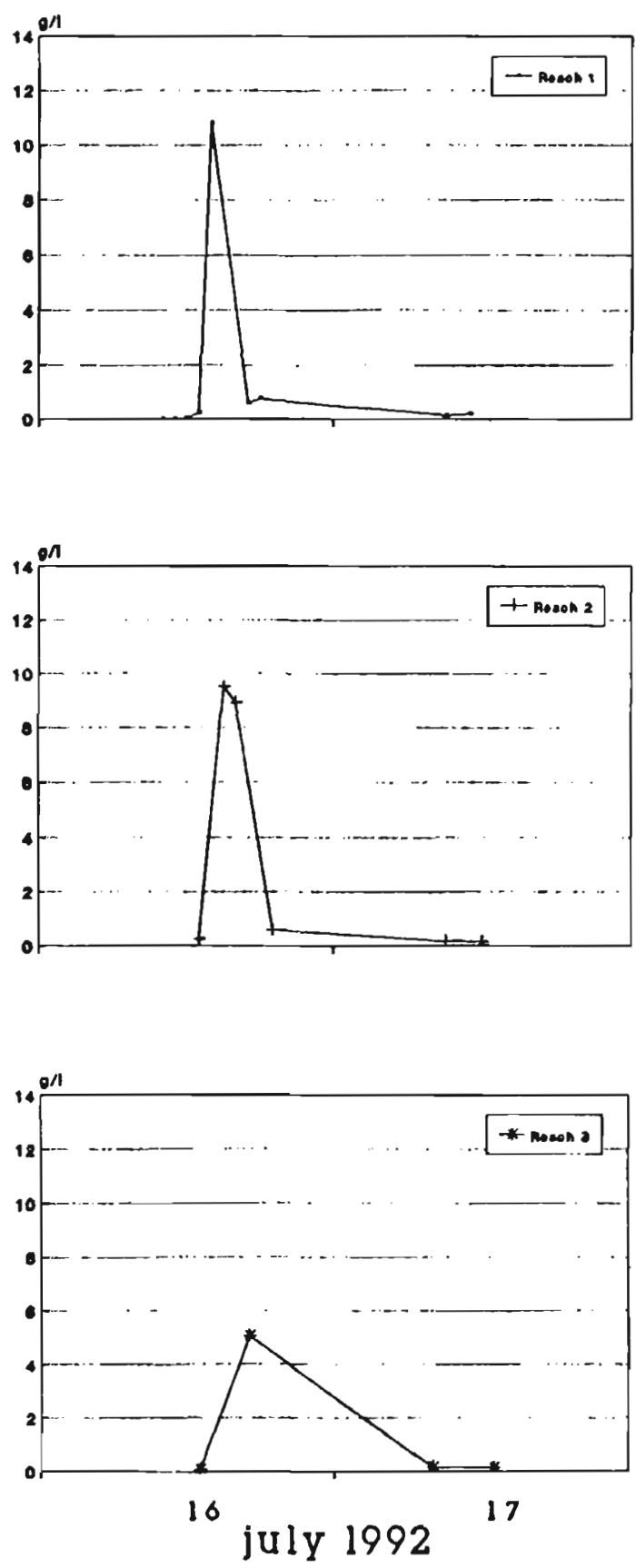

Fig. 7. - Ozola reservoir TSS downstream of the dam after emptying. 
extended as far as $5,5 \mathrm{~km}$ (reach 2), but it did not arrive at the reach 3 (12 km from the dam) (fig. 8).

No EBI score decrease was pointed out.

\section{Riolunato reservoir}

The perturbation of TSS lasted about one week (fig. 9). The increase of TSS at the end of August 1992 was due to a natural flood of the stream; so it affected all the monitoring reaches evenly (being a regional event), while the effects of the drawdown showed a gradient from one to another of them (being a local event).

EBI score decreased from the I to the II quality class in the first two monitoring reaches.

Also an ichthyological quantitative survey was accomplished by electrofishing, in the same locations where EBI was checked, before and after the water release. No noteworthy variation in the structure and in the abundance of fish was pointed out.

\section{Overall remarks}

Table $\mathrm{V}$ summarizes the main results given by the surveys accomplished (maximum TSS, minimum DO and pre-post EBI at the nearest monitoring reach downstream of the dam).

The Corlo reservoir underwent to a cleaning intervention (downstream drifting of about $4 \cdot 10^{6} \mathrm{~m}^{3}$ of sediment), that caused the highest turbidity among the ones reported $(20,8 \mathrm{~g} / \mathrm{l}$ of TSS).

In the other cases, the maximum TSS measured ranged from 8,65 to
$10,8 \mathrm{~g} /$, with the exception of Riolunato (max. TSS $1,6 \mathrm{~g} / \mathrm{l}$ ) and $\mathrm{Li}$ gonchio 1992 (max. TSS 0,16 g/l; this reservoir has a little catchment basin and it had already been emptied in 1991 with a maximum TSS of 9,2 g/l). Despite the level of maximum TSS, oxygen concentration remained good during the whole period of perturbation, also at $1 \mathrm{~km}$ from the dam (minimum DO from 7,9 to $10,4 \mathrm{mg} / \mathrm{l}$ ), because of the low oxygen demand of drifted sediment, so there was not risk of anoxia for stream fauna. In some cases (Boschi reservoir, Ligonchio reservoir 1991), $\mathrm{O}_{2}$ saturation was negatively correlated with TSS, but its value never decreased under $85 \%$. The period of the water quality perturbation ranged from $<2$ days (Ligonchio 1992, Ozola) to $>10$ days (Corlo, Boschi). After this, the drifted sediments remained in the stream bed for some weeks or months, modifying the microhabitat composition of aquatic environment, until seasonal floods removed them.

Macroinvertebrates communities showed to tolerate rather easily water quality variations. The EBI decrease was observed only in the sites affected by the longest perturbations (Corlo, Boschi, Riolunato) and they were limited to shifts of 1 quality class. The spatial extent of these variations attained $6,5 \mathrm{~km}$ from the dam, in the case of Riolunato, and $10,5 \mathrm{~km}$, in the case of Boschi; at Corlo, the confluence of the stream affected by the TSS increase (T. Cismon) with the main river (Brenta river), $3,5 \mathrm{~km}$ downstream of the dam, allowed the 

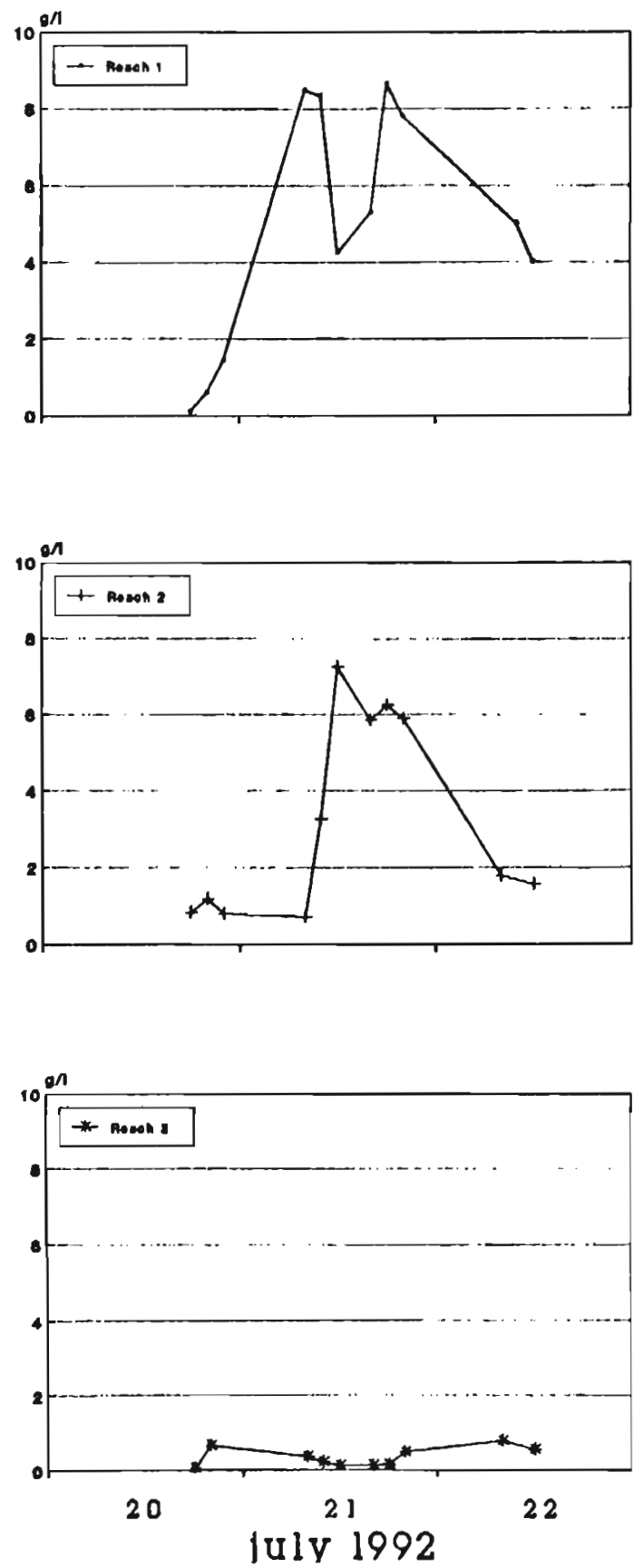

Fig. 8. - Quarto reservoir TSS downstream of the dam after emptying. 

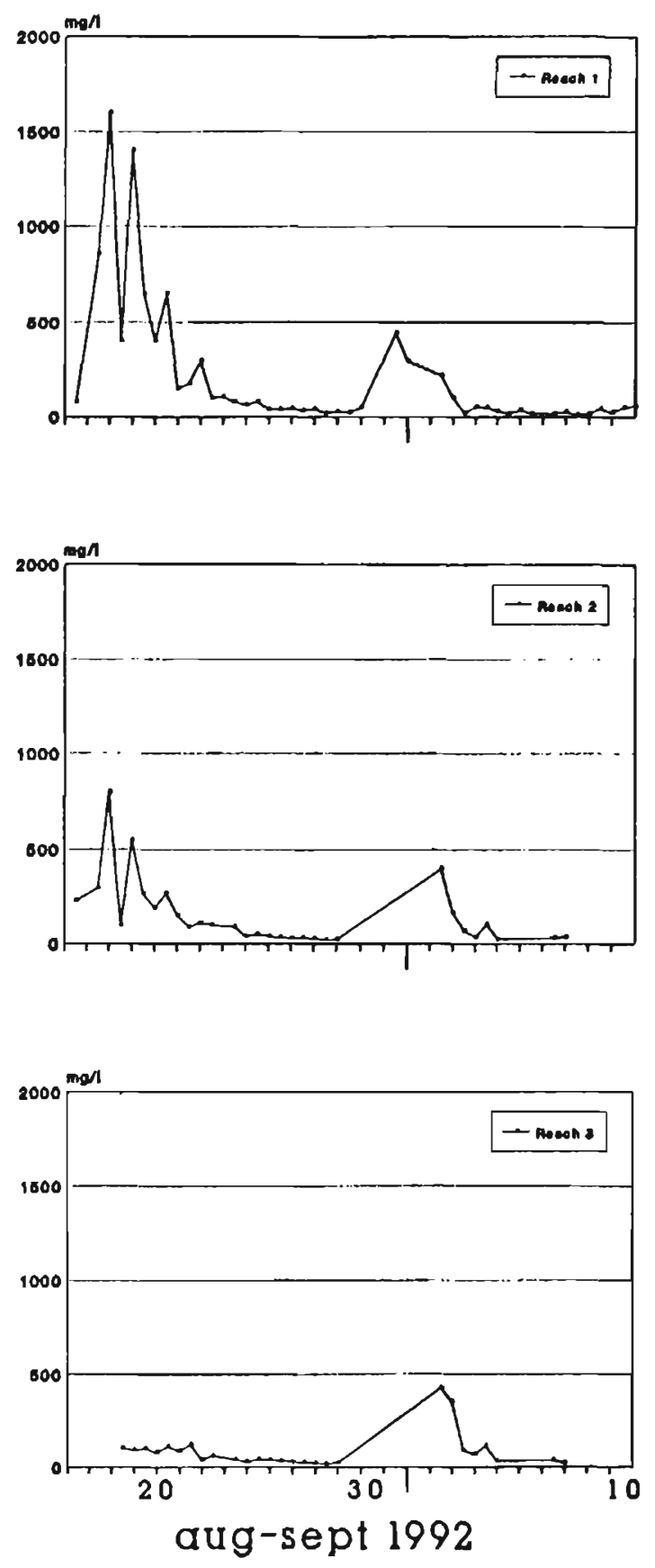

Fig. 9. - Riolunato reservoir TSS downstream of the after emptying. 
Table V. - Extreme concentrations of T.S.S. and D.O. and variation of hydrobiological quality at the nearest monitoring reach downstream of the dam.

\begin{tabular}{|c|c|c|c|c|c|}
\hline & & & & & \\
\hline Reservoir & $\begin{array}{l}\text { Maximum } \\
\text { T.S.S. } \\
\text { (g/l) }\end{array}$ & $\begin{array}{l}\text { Minimum } \\
\text { D.O. } \\
\text { (mg/l) }\end{array}$ & $\begin{array}{l}\text { Perturbation } \\
\text { period } \\
\text { (days) }\end{array}$ & $\begin{array}{c}\text { Pre-operational } \\
\text { E.B.I. }\left({ }^{\circ}\right) \\
\text { (score) } \\
\text { [Quality class] }\end{array}$ & $\begin{array}{c}\text { Post-operational } \\
\left.\text { E.B.I. ( }{ }^{\circ}\right) \\
\text { (score) } \\
\text { [Quality class] }\end{array}$ \\
\hline $\begin{array}{l}\text { CORLO } \\
\text { BOSCHI } \\
\text { LIGONCHIO }\end{array}$ & $\begin{array}{l}20,80 \\
10,80\end{array}$ & $\begin{array}{r}10,4 \\
9,2\end{array}$ & $\begin{array}{l}5 \div 15 \\
5: 15\end{array}$ & $\begin{array}{r}8[\mathrm{III}] \\
10[\mathrm{II}]\end{array}$ & $\begin{array}{l}7 \text { [III] } \\
9 \text { [III] }\end{array}$ \\
\hline $\begin{array}{l}\text { (Oct. 1991) } \\
\text { (July 1992) }\end{array}$ & $\begin{array}{l}9,20 \\
0,16\end{array}$ & $\begin{array}{r}8,8 \\
10,1\end{array}$ & $\begin{array}{r}2: 5 \\
<2\end{array}$ & $\begin{array}{l}9 \text { [II] } \\
9 \text { [II] }\end{array}$ & $\begin{array}{l}9 \text { [II] } \\
9 \text { [II] }\end{array}$ \\
\hline OZOLA & 10,80 & 8,9 & $<2$ & 9 [II] & 9 [II] \\
\hline QUARTO & 8,6 & 7,9 & $2: 5$ & $8[\mathrm{III}]$ & $8[11]$ \\
\hline RIOLUNATO & 1,60 & n.d. & $5 \div 15$ & 10 [i] & 9 [il] \\
\hline
\end{tabular}

$\left({ }^{\circ}\right)=1: 2$ months before drawdown.

$\left({ }^{\circ}\right)=1: 2$ months after drawdown.

macroinvertebrates population to endure the effects of the stress without showing structural modifications.

\subsection{Characteristics of sediments}

The fine materials accumulated on the bottom of some of the reservoirs were tested according the procedural scheme outlined in figure 2, to identify the optimal options for their potential allocation.

The analysis to verify their toxicity and noxiousness showed that they had micropollutants concentrations far lower than the limits imposed by law (DPR 915/1982) to discriminate solid wastes that have to be addressed to special controlled dumping sites.

The leachate analysis showed that the sediments of the Corlo, Riolunato and Quarto reservoirs complied with the prescriptions of $L \quad 319 / 1976$ (tab. VI), so they could be discharged in dumping areas for inert, used for landfilling and river bank reshaping or downstream drifted.

In view of agriculture recycling, the materials sampled at Boschi and at Riolunato resulted in observance of DL 99/1992 from the standpoint of metal concentration, but they did not respect it taking into consideration agronomic characteristics (tab. VII); in that case they could be utilized only for sport fields, gardens, parks.

\section{TENTATIVE GUIDELINES FOR ENVIRONMENTAL MANAGEMENT}

The operation of drawing from the ENEL experiences guidelines to perform extraordinary maintenance of hydroelectric reservoirs in condition of environmental safeguard was accomplished taking also the information from literature into consideration. 
Table VI. - Leachate analysis $\left(\mathrm{CO}_{2}\right.$ saturated water solution).

\begin{tabular}{|c|c|c|c|c|}
\hline \multicolumn{5}{|c|}{$[\mathrm{mg} / \mathrm{l}]$} \\
\hline Elements & CORLO & RIOLUNATO & QUARTO & $\begin{array}{c}\text { Reference limits } \\
\text { (RI) } \\
\text { L 319/1976 }\end{array}$ \\
\hline $\begin{array}{l}\mathrm{As} \\
\mathrm{Hg} \\
\mathrm{Cd} \\
\mathrm{Cr} \mathrm{VI} \\
\mathrm{Pb} \\
\mathrm{Se} \\
\mathrm{Cu} \text { (sol.) }\end{array}$ & $\begin{array}{r}0,0300 \\
<0,0002 \\
<0,0001 \\
0,0010 \\
0,0030 \\
<0,0010 \\
0,0310\end{array}$ & $\begin{array}{r}<0,0010 \\
<0,0001 \\
<0,0001 \\
<0,0005 \\
0,0026 \\
<0,0010 \\
0,0020\end{array}$ & $\begin{array}{r}<0,0010 \\
<0,0001 \\
<0,0001 \\
<0,0005 \\
<0,0005 \\
\quad 0,0020 \\
\quad 0,0010\end{array}$ & $\begin{array}{l}0,5 \\
0,005 \\
0,020 \\
0,20 \\
0,20 \\
0,03 \\
0,10\end{array}$ \\
\hline$\Sigma\left(C_{i} / R I\right)$ & 0,39 & $<0,1$ & $<0,1$ & $<3$ \\
\hline
\end{tabular}

Table VII. - Sediment analysis against agronomic reference values.

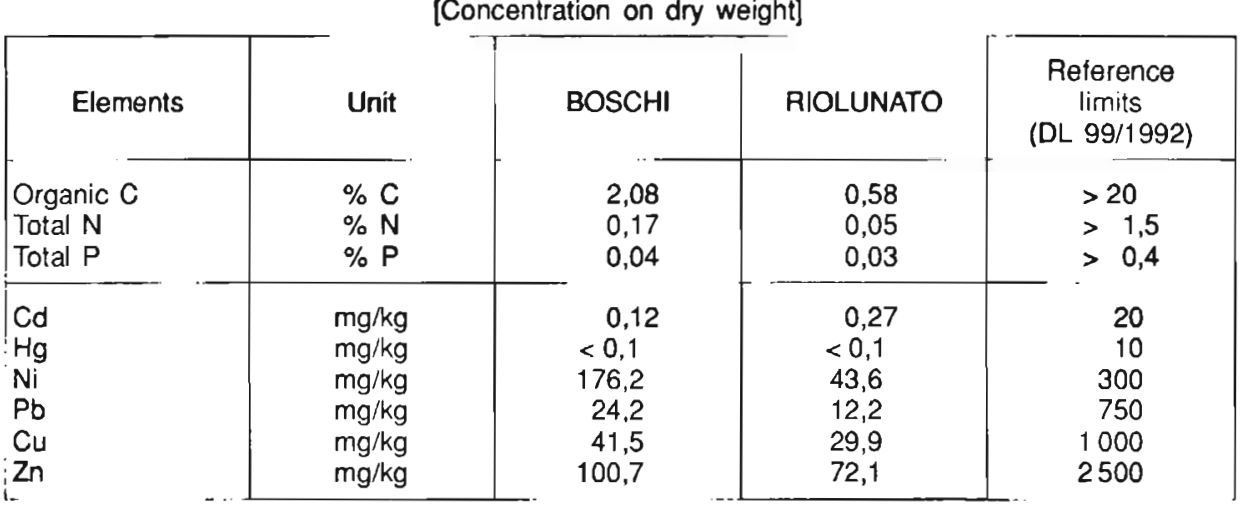

The matter of effects of Suspended Solids and of $\mathrm{O}_{2}$ depletion on aquatic biota has been studied since the twenties. Alabaster \& Lloyd (1982) reviewed exhaustively, from the ichthyological standpoint, the relevant works accomplished up to the late seventies and their publication gave a good basis of information.

Also the experiences of EDF (Electricité de France) were considered; the conclusions of their five years study about environmental concerns linked with emptying reservoirs in France (Cardinal, 1989) were source of very useful interpretations and proposals.

Recently, Newcombe \& MacDonald (1991) made an interesting analysis of more than 70 papers published from 1939 to 1988 about effects of Suspended Sediments on Salmonidae and aquatic Invertebrates. 
These Authors included in their study only the works containing information on concentration of sediment in the water of affected streams, length of time the organisms were exposed to increased turbidity and nature of the biological effects. They grouped effects in three categories (lethal, sublethal, behavioural) and ranked them in 14 classes according to their severity (tab. VIII).

Then Newcombe \& MacDonald tested the regression of the rank versus concentration of sediments and found that the latter variable, alone, is a relatively poor indicator of severity of TSS effects $\left(r^{2}=0,14 ; N S\right)$, while the product of sediment concentration by duration of exposure is more useful from this point of view $\left(r^{2}=0,64 ; P<\right.$
$0.01)$. So they proposed the regression curve of effect rank vs. "intensity" (concentration $x$ time of exposure) developed from the available data (tab. VIII) as a model to predict the severity of effects of Suspended Sediments.

Considering that this study has a large bibliographic basis and that its conclusions are referred largely to sensitive species (Salmonidae), this model was taken as a reference for determining the guidelines for performing the extraordinary maintenance operations in ENEL hydroelectric reservoirs in condition of environmental protection.

As regards effects of $\mathrm{O}_{2}$ depletion on aquatic biota, at present the most up-to-date review on the matter is a

Table VIII. - Ranks of effects of Suspended Solids on fish and aquatic life and predictive model proposed by Newcombe \& MacDonald (1991).

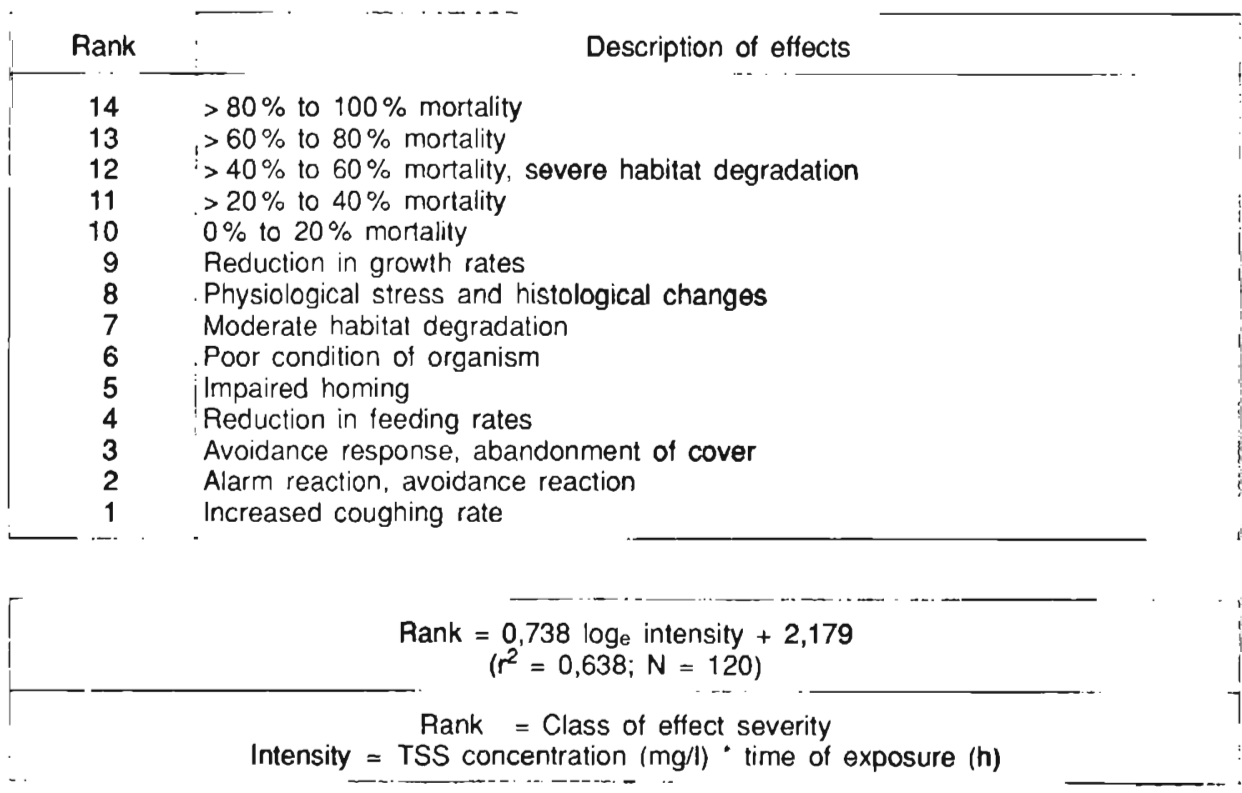


specific publication of US-EPA (1986), that concludes suggesting 4 and $3 \mathrm{mg} / \mathrm{l}$ as daily minimum acceptable level of DO, respectively for adults of Salmonidae and of Cyprinidae; for aquatic macroinvertebrates, according to this paper, the minimum concentration of DO under which acute mortality phenomena can take place is $4 \mathrm{mg} / \mathrm{l}$.

ENEL guidelines for environmental management of extraordinary maintenance operations of hydroelectric reservoirs consider two aspects:

- downstream effects of drawdown and sediment removal,

- allocation of filling materials.

For both of them, the guidelines specify the parameters to be monitored, their suggested reference limits, the experimental design and the sampling and measurement techniques for their monitoring.

These guidelines constitute the first step in dealing with the problem of environmentally sound management of this type of interventions and they could be modified by further experiences.

\subsection{Criteria and reference limits for the execution of hydraulic operations of emptying and clea- ning hydroelectric reservoirs}

\section{Emptying operations}

Criteria: as the periodicity of this operation for a reservoir is pluriannual, the theoretic possibility of accepting little transitory losses of downstream biological resources is admitted.
According to the predictive model proposed by Newcombe \& MacDonald (1991), the lowest losses caused by Suspended Sediments in aquatic biota (0 to $20 \%$ ) are in relation with an "intensity" (concentration $x$ time of exposure) of TSS of about $40 \mathrm{~g} / \mathrm{l}$ for $1 \mathrm{~h}$, that can be considered equivalent to $10 \mathrm{~g} / \mathrm{l}$ for $4 \mathrm{~h}$, from the standpoint of severity of effects.

Reference limits: during the emptying operation, for the above criteria, it is suggested as maximum acceptable level of TSS, at about $0,5 \mathrm{~km}$ downstream of the dam, after that the flood front has arrived, the concentration of $10 \mathrm{~g} / \mathrm{l}$ as 4-hours average.

In case of overcoming, the necessary intervention to lower TSS concentration (dilution, water release interruption) must be accomplished.

Cleaning operations by downstream drifting sediment

Criteria: considering that this operation is accomplished less than once in ten years, the theoretic possibility of accepting tangible losses of downstream biological resources is admitted.

According to the predictive model of Newcombe \& MacDonald (1991), hydrobiological losses from 20 to $40 \%$ caused by Suspended Solids are in relation with an "intensity" (concentration $\times$ time of exposure) of TSS of about $160 \mathrm{~g} / \mathrm{l}$ for $1 \mathrm{~h}$, that can be considered equivalent to $40 \mathrm{~g} / \mathrm{l}$ for $4 \mathrm{~h}$ and to $6,5 \mathrm{~g} / \mathrm{l}$ for $24 \mathrm{~h}$, from the standpoint of severity of effects. 
As these values can influence the water oxygenation notably, also a reference limit for DO is considered.

Reference limits: during this operation, at about $0,5 \mathrm{~km}$ downstream of the dam, after that the flood front has arrived, the following reference limits are suggested:

- maximum hourly TSS : $100 \mathrm{~g} / \mathrm{l}$

- maximum TSS $4 \mathrm{~h}$ average : 40 g/l

- maximum TSS daily average : $6,5 \mathrm{~g} / \mathrm{l}$

\section{- minimum DO : $4 \mathrm{mg} / \mathrm{l}$}

For situations in which sediments have high organic fraction (>15\%) and water has $\mathrm{pH}>8$, monitoring undissociated $\mathrm{NH}_{3}$ is suggested; in observance of the legislative act $\mathrm{DL}$ 130/92 (Quality of water bodies for the protection of freshwater fish), this parameter cannot exceed $0,025 \mathrm{mg} / \mathrm{l}$.

The reference limit for DO (and, in case, of $\mathrm{NH}_{3}$ ) must be respected at each stretch of the stream affected by increased turbidity.

In case of overcoming, the necessary intervention to lower TSS concentration (dilution, water release interruption) must be accomplished.

To evaluate the eventual losses of biological resources and the time of their recovery, macroinvertebrates populations may be monitored before and after the hydraulic operations, to estimate the hydrobiological quality variation of the stream by determining the Extended Biotic Index (EBI). In sites of particular naturalistic importance, also an ichthyological quantita- tive survey may be accomplished, before and after the cleaning operation.

\subsection{Criteria and procedure for the allocation of filling materials}

When it is necessary to remove deposit materials from reservoirs, guidelines suggest the criteria and the procedure to classify and to allocate them in an environmentally sound way, considering also all the recycling possibilities.

Materials that accumulate on the bottom of the reservoirs can be grouped in two categories:

- rocks and lithoid materials,

- fine sediments.

\section{Rocks and lithoid materials}

This category is considered inert and the employment in natural environment for intervention of land shaping is included among its potential fields of utilization; in particular it is suggested to use it:

- for stream bed reshaping and bank or coast consolidation,

- as building material, reducing the extraction of inert from other natural sources.

\section{Fine sediments}

In order to identify the optimal options for the allocation of fine materials accumulated on the bottom of the reservoirs, the guidelines adopt the procedure of analysis and classification outlined in figure 2.

Besides, the guidelines specify the experimental design for sampling fine 
sediments in the reservoirs and the techniques for analyzing them and for estimating their volume.

\section{CONCLUSIONS}

In Italy, in the last decade, the attention focused on environmental concerns related to emptying and desilting hydroelectric reservoirs has become more and more intense, because of the increase of the rate of sedimentation in most of them, as well as of the process of progressive strengthening of the awareness of public opinion towards environmental issues.

A national specific environmental legislation to regulate reservoirs maintenance operations is still under study, so the problem of their authorization must be faced up on the basis of case by case agreements with local Public Administrations, that lack experience and terms of reference.

The systematic approach to this issue chosen by ENEL was adopted to constitute a homogeneous set of information on environmental effects of emptying and desilting hydroelectric reservoirs in the Italian context, with the objective to propose to competent Authorities reference limits and a procedural scheme for the licencing process.

The management guidelines described in this paper are the result of this effort and, in theory, they seem to have good perspective of success. Nevertheless, before they are con- sidered by Lawmakers in real terms, they need to be tested in practice.

At present, after having used its knowledge in this field to make ready this proposal, ENEL is carrying out a new series of experiences by implementing it in real cases, to demonstrate the process feasibility and to check its environmental effectiveness. The proposed management guidelines, in fact, have been incorporated into a code of conduct for emptying and desilting hydroelectric reservoirs, uniform for the whole Company, that is applied to all new maintenance operations, under the control of Public Administrations. The results of this implementation will constitute an useful term of reference for the preparation of the national legislation to regulate this type of operations.

\section{REFERENCES}

Alabaster J.S., Lloyd R. (1982). Finely divided solids. In J.S. Alabaster \& R. Lloyd (Eds.) : Water quality criteria for freshwater fish. Buttenworths, London: pp. 1-20.

Cardinal H. (1989). Bilan des recherches et recommandations en matiere de vidanges de retenues - Procedure $\mathrm{Li}$ vre. EDF, Chatou (F); HE-31/88.20.

ENEL SpA DCO (1989). Controlio della qualità dell'acqua del fiume Brenta durante le operazioni di svaso del serbatoio del Corlo. DCO/Laboratorio Centrale di Piacenza (amCA/17/89/E).

ENEL SpA DCO (1991). Controlli chimicofisici e biologici a seguito delle operazioni di svaso del serbatoio di Ligonchio. DCO/Laboratorio Centrale di Piacenza (ecEL/38/91/F). 
ENEL SpA DCO (1992). Controlli chimicofisici e biologici a seguito delle operazioni di svaso del serbatoio di Boschi. DCO/Laboratorio Centrale di Piacenza (ECL/CA/50/92/F).

ENEL SpA DCO (1992). Controlli chimicofisici e biologici a seguito delle operazioni di svaso del serbatoio di Quarto di Romagna. DCO/Laboratorio Centrale di Piacenza (ECL/CA/51/92/F).

ENEL SpA DCO (1992). Controlli chimicofisici e biologici a seguito delle operazioni di svaso dei serbatoi di Ligonchio e Ozola. DCO/Laboratorio Centrale di Piacenza (LPEE/59/92/F).

ENEL SpA DCO (1993). Controlli chimicofisici e biologici a seguito delle operazioni di svaso del serbatoio di
Riolunato. DCO/Laboratorio Centrale di Piacenza (9100317TSIPE030).

Ghetti P.F. (1986). I macroinvertebrati nell'analisi di qualità dei corsi d'acqua. Provincia Autonoma di Trento. 106 pp.

Newcombe C.P., MacDonald D.D. (1991). Effects of suspended sediments on aquatic ecosystems. N. Am. J. Fish. Man. 11: 72-82.

Verneaux J. (1973). Les principales méthodes biologiques de détermination du degré de pollution des eaux courantes. Econ. et Med. Anim., 1973 (14): 1.

Woodiwiss F.S. (1964). The biological system of stream classification used by Trent River Board. Chem. \& Ind. 14: 443-447. 